\title{
Geopolitical Regionalisms Resulting From US-Led GWOT, Colour Revolutions and Arab Spring: Implications for Turkish Defence and Foreign Policy
}

\author{
Teröre Karşı Küresel Savaş, Renkli Devrimler, ve Arap Baharı'ndan \\ Jeopolitik Bölgeselciliğe: Türk Savunma ve Dış Politikasına Etkileri
}

Greg SIMONS ${ }^{*}$ iD

\begin{abstract}
Geopolitical regionalisms are a mechanism of managing influence in a particular region at a particular point in time. They exist and are driven by powers vying for influence at the expense of others, in turn influenced by the nature of the geopolitical era in which they exist. The Cold War saw a bipolar world, where geopolitical regionalisms were achieved by the two superpowers, often through their proxies. This was replaced by a monopolar world order after the collapse of the Soviet Union in 1991. The current transforming global order towards a multipolar world has created a lot of chaos through the United States seeking to maintain its global hegemony and thwart competition. This is accomplished through creating branded events in international relations, such as the Global War on Terror or the Arab Spring. The goal is to manage the international system as envisaged by the strategic imperatives mentioned by Brzezinski in 1997, through weakening opponents and keeping allies dependent. As such, tremendous challenges have been created for Turkey in handling its foreign and security policy interests as a regional power in the Middle East.
\end{abstract}

Keywords: Turkey, Global War on Terrorism, Arab Spring, geopolitical regionalisms, foreign and security policy, branding international events

Öz

Jeopolitik bölgeselcilik belli bir bölgede belli bir zamanda etki yönetme mekanizmasıdır. Bu amaçla aktörler, içinde bulundukları jeopolitik dönemin doğasından etkilenirken, başkaları pahasına var olmak ve güç elde etmek adına mücadele ederler. Soğuk Savaş dönemi, jeopolitik bölgeselciliğin iki süper güç tarafından, genellikle vekilleri aracılığıyla elde edildiği iki kutuplu bir dünyaya şahit oldu. 1991'de Sovyetler Birliği’nin yıkılması ile tek kutuplu dünya düzeni hâkim hale geldi. Günümüzde çok kutuplu dünyaya doğru evrilen bu küresel düzenin dönüşüm süreci ise sancilı oldu. Dünya çapında hegemonyasını korumaya ve rekabeti engellemeye çalışan ABD bu dönüşümün sancılı olmasında büyük rol oynadı. ABD hegemonyasını devam ettirmek için Teröre Karşı Küresel Savaş veya Arap Baharı gibi olayları markalaştırarak uluslararası ilişkilerin temel konusu haline getirdi. ABD’nin bununla ulaşmak

* Institute for Russian and Eurasian Studies at Uppsala University in Sweden and the Humanitarian Institute at Ural Federal University in Russia, E-mail: greg.simons@ires.uu.se, ORCID: https://orcid.org/0000-0002-6111-5325 
istediği hedef, Brzezinski’nin 1997’de belirttiği stratejik zorunlulukların öngördüğü uluslararası sistemi, muhalifleri zayıflatarak ve müttefikleri bağımlı tutarak yönetmekti. Bu iklimde, Ortadoğu’da bölgesel bir güç olarak Türkiye’nin dış ve güvenlik politikası çıkarlarını gerçekleştirmesinde ciddi zorluklar yaratılmıştır.

Anahtar Kelimeler: Türkiye, Teröre Karşı Küresel Savaş, Arap Baharı, Jeopolitik bölgeselcilik, Dış ve güvenlik politikası, Uluslararası Olayları Markalaştırma

\section{Introduction}

The role of branding and reputation management is playing an increasingly important role in the management of international relations. These are intended as mechanisms to shape the cognitive realm through subjective representations of the physical realm via the information realm. There is a tendency for people to react to what they perceive as being the truth, rather than what is necessarily the truth as it may differ. The effects can be both powerful for the communicator and disempowering for others. Sussman (2010) gives an excellent example of this within the context of a branded process of the collapse of Central and Eastern Europe, which saw the use of the concept of democracy to simultaneously empower the political opposition supported by the West and disempower the incumbent governments of the rapidly collapsing Eastern Bloc. There are various branded events within international affairs of the $21^{\text {st }}$ century too, such as the Global War on Terrorism (GWOT), the Colour Revolutions and the Arab Spring.

These are indicative of geopolitical regionalisms, where great powers seek to expand their own influence and power and/or limit the influence and power of their competitors and rivals. Geopolitical regionalisms can be positive or negative, inclusive, or exclusive depending on the circumstances of the time and place. This paper shall look at the specific events of the GWOT, Colour Revolutions and Arab Spring as being branded events within the framework of geopolitical regionalisms. The added problematic dimension is to understand how Turkish foreign and security policy is affected by these events that are intended to satisfy the strategic imperatives of the United States as outlined by Brzezinski (1997). The changing nature of geopolitics and national goals and interests has caused confusion concerning the nature of the relationship between Turkey and the US, and what the exact role is now played by Turkey in its neighbourhood (Lesser, 2006).

In this article there are four main sections, the first of which deals theoretically with the issue of branding of events occurring in international relations. What is a brand? How does a brand relate to geopolitical events and trends? The second section moves to the topic of geopolitics and geopolitical regionalisms. What are they? Why do they occur? Evolution and change in Turkish foreign and security policy in the post-Cold War world is the subject of section three. The fourth section of the article moves to examining four separate, and yet linked aspects. There is firstly, the appearance of the term "Neo-Ottoman" foreign policy and its likely intended effect on the foreign and security policy choices of Turkey. It is followed by the branded events of the GWOT, the 
Colour Revolutions and the Arab Spring, together with the restraints and constraints on Turkish interests and security.

\section{Branding International Relations Events}

Branding is a standard philosophy and practice in the contemporary business and political environments. It is an indispensable aspect of organisational activity, depending on the conceptual underpinnings and the execution of the practical approach, it can be the difference between success and failure in attaining organisational goals and objectives. In way of a basic definition of the term and its implications, the following provides an overview. "Branding is the process by which companies differentiate their products from their competition. In developing a unique identity, which may include a name, packaging and design, a brand is developed. In developing and managing this unique identity, the branding process allows organisations to develop strong emotional and psychological connections with a product, goods, or service. This in turn, eases the purchasing decision. Branding affects stakeholder perceptions, and the marketing task is to ensure these perceptions are positive" (Franklin et al, 2009, p. 33).

A brand is a significant step in the road to creating and maintaining an enduring mutually reciprocal political relationship between the messenger and the audience. A series of steps are used by marketers to embark on establishing a brand. The first step is to build awareness through communication concerning a particular product or service on offer, which is likely to increase engagement and interaction. Step two concerns positioning of the product or service, once the consumer is aware of it. This is an attempt to differentiate it from its competition. The third step is about establishing a brand after awareness and positioning are implemented. Then automatic associations and assumptions are connected to the brand of a particular product or service (Newman, 2016, p. 112). There are three different aspects to be examined when evaluating the strength of brand value. Differentiation is used to distinguish a product, service, or organisation from competing brands, and thereby be better able to position itself more ideally to enable better reach and connection with the target audience. A brand's visual identity is a key aspect in helping an audience to better identify the difference and believe in it. Credibility of a brand is an icon of trust and credibility, with the intention of helping to develop a loyal following. An organisation's credibility is achieved by its ability to live up to its promise(s). Authenticity is gained by matching words and deeds. Efforts are also needed to draw in a wider audience and not just those individuals that are directly affected or concerned by an issue (Matusitz, 2015, p. 241). The aspects identified above are concerning the pursuit of brand management.

Brand management is a communication function that consists of examining and planning how a brand should be positioned in the world, to what type of audience the brand should be targeted, and how ideal the reputation of the brand should be preserved. Brand management is an example of public communication. Public communication is a purposive effort to inform or 
affect the behaviours of large audiences within a specific set of time using a coordinated set of communication activities (Matusitz, 2015, p. 241).

The above-mentioned engagement with branding is mostly in reference to people or entities, however, processes and trends can also be subjected to branding. This can be more pronounced in times of crisis and/or conflict owing to the potential for issue and reputation management, where manufacturing and engineering public perception is a key to managing public opinion and reaction. However, the owner of the brand and reputation is not necessarily the actor that is shaping it.

An approach that shapes the brand and reputation of person, organisation, object, or event is the notion of obstructive marketing. This concept is often misunderstood, as when it is assumed to involve negative marketing. However, obstructive marketing is much more complex than this rather simplistic view.

It can be defined as:

Any process, ethical and legal or not, which prevents or restricts the distribution of a product or service, temporarily or permanently, against the wishes of society, shareholders, management, staff or procedures of the product manufacturer, service provider or customer (Hyslop, 2014, p. $11)$.

From this definition, obstructive marketing plays an oppositional role in the image and/or brand of a person, product, or service. This can be applied to adversely affect a target's image and brand. Within the context of a person, organisation or country's reputation and brand, obstructive marketing aims to erode the competitive edge to reduce operational capacity and choices. This can be done in at least two ways: product depreciation - "doing a product down in some way" (Hyslop, 2014, p. 52) - and product contamination - "where the product becomes damaged in some way" (Ibid). These methods attack a politician's (applicable to other subjects and objects too) most vulnerable front: his or her intangible value and perception. In the current informational environment, the "Internet is a rich source of information and a conduit for obstructive marketing” (Hyslop, 2014, p. 223).

Attempts to "brand-jack" a particular country provides an opportunity for the perpetrator to condition an audience to develop a negative emotional relationship if that country loses control of their projected public image. The next logical step is to create a "spark" that ignites the indignation of a primed audience, such as by putting the now-negative persona into a concrete public event laced with negative political symbolism, with the goal of transforming intangible feelings and emotions into tangible expressions and actions. Here the political programme can possess tangible and intangible geopolitical objectives. 


\section{Geopolitical Regionalisms}

In some circles, the United States views itself as an "indispensable" power, which is based upon the notion of its unchallenged superiority in military, economic, technological, and cultural power. There was also the belief that there could be no single actor with sufficient power and resources to challenge the US global hegemony. ${ }^{1}$ However, this necessitates preventative measures to ensure other powers or blocks of powers gain power and influence. A quote from Zbigniew Brzezinski (1997) illustrates the underlying reason and motivations for influencing regionalisms. "In brief, for the United States, Eurasian geostrategy involves...three grand imperatives...to prevent collusion and maintain security dependence among the vassals, to keep the tributaries pliant and protected, and to keep the barbarians from coming together." Although understanding the tangible and practical aspects of this strategy, through being able to understand and anticipate the intangible communicational aspects is likely to bring greater benefits. This is owing to the contagious psychological basis of such policy and actions. Considering Brzezinski's observations pertaining to the goals of US geostrategy, which can be seen within the context of geopolitics, its very definition is essential to understanding how processes and events are managed by international actors.

Geopolitics is, definitionally, the art and process of managing global rivalry; and success, again definitionally, consists at a minimum of consolidating the strength and cohesion of the group of nations which form the core of one's power position, while preventing the other side from extending the area of its domination and clientele (Jay, 1979, p. 486).

Jay (1979) refers to positive and negative geopolitical regionalisms. Positive regionalisms involve environmental circumstances and trends aligning and enabling an actor's geopolitical aims and interests, whereas negative regionalisms refer to when circumstances align to the contrary and prevent the realisation of those goals and interests. As noted by Rumley (2005, p. 5), regionalisms are very much something that is constructed by man, rather than something that is naturally occurring, which is a cause for it to be contested at both the theoretical and practical levels. Regionalism is conceived in both a formal and informal sense. It is often associated in a sociocultural sense in the context of a sense of belonging or being to a particular group (Vilanova, 2013, p. 18-20). In addition, "regionalism can become a rationale for policies associated with stability and control within a perceived sphere of influence" (Rumley, 2005: 6). A more formal understanding of regionalism is often created to meet certain functions, including those of state (economic, security or environmental). It often comes within a deterministic framework, such as geographical contiguity, and an implied degree of interest congruence between states (Jay, 1979; Tsantoulis, 2009).

Regionalisms can also be narrated as being inclusive or exclusive in nature, through including or excluding specific countries, actors, ideas and so forth. This creates a binary constructed reality,

1 Brzezinski,Z.,A GeostrategyforEurasia,CommonwealthInstitute, http://www.comw.org/pda/fulltext/9709brzezinski. html, September/October 1997 (accessed 19 March 2018) 
where actors involved opt to accept or reject the two options - accept/reject globalisation or accept/reject nationalism (Rumley, 2005, p. 8). This can also be taken on a more abstract level of norms and values too, where the choice is for or against "democracy" and "international norms and values." These are the fundamentals in creating a facade for the narrative of a battle of 'good' against 'evil' that is waged via manipulating and influencing global public perception and opinion.

The end of the Cold War and the bi-polar system of superpower global domination in 1991 has seen new imperatives in geopolitics and regionalisms emerge. What came afterwards was the result of the excesses of neo-liberalism that manifested after the collapse of checks and balances in the international system. Current US military and economic global hegemony is a mechanism that is used to deter, prevent, or destroy any emerging regionalisms that threaten that hegemony. As a result, neo-liberalism destabilised the international system caused several conflicts and tensions of a military and an economic nature. When the US emerged from the Cold War as the sole superpower it was also a global informal empire. Historically the US has used a combination of military and economic power to influence geopolitical regionalisms, such as the Marshall Plan in Western Europe after World War Two to gain influence and control, at the same time to prevent Soviet influence and control.

A significant change took place in Brzezinskis thinking from 1997 until 2016, when he wrote Toward a Global Realignment, where he no longer boasts of the United States being an unchallenged global power. The challenges to US power and influence came from China, Russia and a political reawakening in the Middle East and Muslim worlds. ${ }^{2}$ As such there has been a reaction to the seemingly 'unstoppable' advance of global liberalism. "The emergence of these new forms of neo-liberal globalisation and related forms of militarisation pose some of the sharpest challenges for human security today."3 The waves of branded revolutions, in particular the Global War on Terrorism (GWOT), Colour Revolutions and the Arab Spring, can be seen in the light of Brzezinski's stated geostrategic goals within the framework of neo-liberal expansionism. These trends and events all carry significant security and foreign policy implications and challenges for Turkey. Branding in international relations is where an information programme intends to support foreign policy programmes through influencing intangible values that are related to cognitive understandings generated about the physical world among target audiences.

Branding in international relations and foreign policy is intended to cognitively affect the manner that events and processes in the political and geopolitical environment are perceived and the resulting opinions and reactions by stakeholders. For example, branding can be used to try and increase the strengths and opportunities for an actor by influencing a more positive attitude and relations with key stakeholders (Simons, 2011). Branding can also be used as a means of subverting the interests and influence of other actors (increasing their weaknesses and threats)

2 Brzezinski, Z., Toward a Global Realignment, American Interest, https://www.the-american-interest.com/2016/04/17/ toward-a-global-realignment/, 17 April 2017 (accessed 19 March 2018)

3 Reifer, T. E., Geopolitics, Globalisation and Alternative Regionalisms, Transnational Institute, https://www.tni.org/es/ node/11420, 1 September 2002 (accessed 14 June 2017) 
by a competing actor (Sussman, 2010). The actor-based sources of brand influence are wide and varied in the contemporary international relations environment (governments, international governmental organisations, NGOs, GONGOs, education sector, national sports, corporations and business enterprises, mass media outlets, think tanks and armed non-state actors) (Dinnie, 2008; Aronczyk, 2013; Eggeling, 2020). The presence and interaction of brands, ideologies (imagining of self-identity and purpose) and geopolitical transformations simultaneously constrain and create opportunities and threats for emerging foreign policy actors in their pursuit of their interests and policy independently from those of greater powers.

\section{Post-Cold War Evolution of Turkish Foreign and Security Policy}

During the period of the Cold War, Turkey served the function as the frontier and a barrier between the US-led Western Bloc and the Soviet Union-led Eastern Bloc in a bipolar global order. Geopolitical regionalisms were dominated by the United States and the Soviet Union, often using their proxies. The geographical location of Turkey meant that it was in a very contested and strategic geopolitical position, in part to manage the Soviet influence and expansion in the region. Turkey served as part of a geopolitical regionalism through its NATO membership of excluding the Soviet Union and its allies (Larrabee, 2010). Due to the proximity to the Eastern Bloc and being part of the Western Bloc, Turkey was security dependent on the United States owing to the risk of large-scale armed conflict. There was relatively little room to enable the creation of independent (from the superpowers) foreign and security policy, even if this would entail pursuing self-interest of the country concerned. As such, Turkey often found itself in the position as an object rather than a subject of international relations.

However, the collapse of the Soviet Union and the end of the Cold War in 1991 has brought about several threats and opportunities that did not exist earlier. The global order transformed from a bipolar system to a unipolar system, where the United States became the global hegemon. This created a series of foreign and security policy operational choices and opportunities to emerge for the United States that has had a significant and profound influence on Turkey's place and role international relations, especially in the former Soviet Republics and the Middle East North Africa (MENA) region.

From the perspective of the US, Turkey stands at the nexus of four strategically significant geopolitical areas of interest - the Balkans, Middle East, Persian Gulf region and the Caucasus/ Central Asia. And Turkish cooperation is considered as being essential to achieving US foreign policy goals (Larrabee, 2010: 1). However, when reflecting on the exact terminology of geopolitics as envisaged by Brzezinski (1997) - "vassals", "tributaries" and "barbarians" there is seemingly little room for the country working with the United States to be seen as a partner, let alone be able to secure its own interests and goals if they diverge.

During the beginning of the $21^{\text {st }}$ century Turkey attempted to transition from a hard power brand that relied heavily on military power and coercion, to include soft power elements. Turkey sought 
to de-securitize its policy approach and to gain credibility among both Western and Middle Eastern countries. One of the routes to achieve this was through the increased importance of trade and economic factors in Turkey's foreign policy (Özdemir \& Serin, 2016). The transition to a soft power model of foreign policy had the potential to position Turkey as a bridge between the West and Middle East, not only in terms of geography, but through foreign policy and politics as well (Oguzlu, 2007). However, the soft power approach was dependent on domestic political and security factors and the level of (in)stability in the regional neighbourhood, not to mention the quality of relations with the West.

When it was becoming apparent that membership to the EU was unlikely and as relations soured with the US, Turkey sought to formulate a more independent path that blended the pragmatism that came with the Turkish Republic's founding, Kemal Ataturk's policy and vision of peace at home, peace abroad, to solve contemporary problems and dilemmas. This was seen with the "new activism" that included what Foreign Minister Davutoglu referred to as the zero-problem policy with neighbours. This approach sparked a lot of criticism including: the zero policy does not mean that existing problems are being solved; improvement of relations with neighbours does not necessarily constitute an alternative Western path; and the solution of problems does not solely rely on Turkey (Ruma, 2010, p. 137). There is a complex set of mutually influencing domestic and foreign factors from the past and present that interact and form Turkey's foreign policy approach.

Before the upheavals of the Arab Spring, but after the chaos of the Iraq War and Colour Revolutions, Ahmet Davutoglu stressed the need to broaden and diversify Turkey's foreign policy, to engage in a much more pragmatic and independent basis that would enable the country to broaden participation in regional matters, assert itself proactively in its regions of interest to pursue goals and interests (Davutoglu, 2008). The message being that Turkey needed to reorientate its foreign policy to consider the new regional and global developments. Bilgin and Bilgic (2011, p. 191) observed both a change and a consistency in AKP's (Justice and Development Party) 'new' foreign policy. For example, there was a shift in the policy makers' view of Central Asia and the Middle East as source regions of chaos and instability towards the sense of a new neighbourhood. Another evolution witnessed Turkey's relations with the surrounding regions as transforming from hesitant engagement to the zero-problem policy. However, these changes had already begun to occur earlier. Ahmet Davutoglu was appointed Foreign Minister by Prime Minister Erdogan on 1 May 2009. He has been credited with the changes in the framing and creating a multidimensional approach of Turkish foreign policy (Aras, 2009). Davutoglu spoke of Strategic Depth, where so-called bridging countries (such as Turkey) as either being based upon a strong identity and sense of self-confidence or those lacking self-confidence take a more pragmatic route (Murinson, 2006; Yanik, 2011, p. 87). The pursuit of a more independent foreign and security policy has created a set of observations and predictions as to where this may lead Turkey in terms of its international relations path and outcome. 
Turkey's approach towards the West is now more pragmatic than ideational. Relations with the US and the EU are important as far as they help Turkey deal with the challenges of the globalisation process rather than confirm Turkey's Western identity, and that Turkey would certainly increase its leverage vis-à-vis the West if it capitalised the Eastern and Islamic aspects of its national identity (Oguzlu, 2008, p. 17).

During the AKP era there has been a gradual evolution that has seen a lesser importance and stress attached to the Europeanisation vector, and a gradual introduction of what some have termed as a "soft Euro-Asianism" (Önis \& Yilmaz, 2009). The issue is not about splitting with the West but changing the quality of the relationship with it to be able to better satisfy the demands and goals of self-interest in foreign and security policy through a more pragmatic and independent approach. Some have observed this need for international partners, such as the US need to understand this change, and the possibility of the ambition for Turkey to aspire to become a regional hegemonic power in the event of actors such as the US leaving a particular region (Erickson, 2004). Turkey's foreign policy identity and orientation is evolving, which reflects the changing dynamics of the country's relations with the US and EU (Oguzlu, 2004). One observer labelled the changing dynamics of relations as the rise of "Turkish Gaullism" as opposed to the binary opposition of Western versus Eastern or secular versus Islam contradictions at play (Taspinar, 2011). These trends have created alarmist questions as to whether Turkey is leaving the West (Cagaptay, 2009). Although, others would argue that this is the wrong question to pose, because "Turkey's cooperation with the West in the years to come will likely depend more on the attitudes of the West towards Turkey than on other factors" (Oguzlu, 2008, p. 17).

\section{GWOT, Colour Revolutions, Arab Spring and Effects on Turkish Interests}

In the post-Cold War era, Turkish foreign and security policy has gradually evolved because of the regionalisation of strategic and security outlook. This has entailed Turkey adopting a more activist regional approach where the geopolitics of Turkey's foreign and security policy are proactively pursued (Kaliber, 2013), and in doing so they sometimes contradict the activities of other powers in those regions. There have been several significant security and foreign policy challenges presented to Turkey in the beginning of the $21^{\text {st }}$ century, which has been created by US attempts to either expand its influence or limit the influence of other powers. This is clearly seen through the creation and management of so-called branded conflict and revolutions. Branding and reputation management is increasingly used to shape the cognitive realm through subjective representations in the information realm of events taking place in the physical realm. By using brands, it is hoped to use information to enable operational choices for the communicator that may not ordinarily be available, whilst at the same time denying operational choices to rivals and competitors.

The sample material collected for this article was found via a general Google search and a Google Scholar search in July 2019. Search terms that were entered are: Neo-Ottoman foreign 
policy; Global War on Terrorism + Turkey; Iraq War + Turkey; Turkish foreign policy interests + GWOT/Iraq; Turkish foreign and security policy interests; Colour Revolutions + Turkey; Arab Spring + Turkey; Arab Spring + Turkish foreign policy interests. Some 40 articles were manually selected by scrolling through the hits, which were based upon the closeness and proximity of the primary interests of this paper, namely how Turkish foreign and security policy interests are affected and influenced by the selected branded revolutions and war according to the frames of the selected sample of analytical and academic papers. This is not a large $\mathrm{N}$ sample; therefore, the result should be understood as being an indicative one and not a representative one, which would require a much larger sample. These articles were analysed using the Critical Discourse Analysis method as outlined by employing a critical dimension in the theoretical and descriptive analyses and evaluations of those texts seen through the relations of power. This is motivated by the inherent embedded relationship between discourse and political power in politics and international relations that is derived through meaning "as constructed during production or comprehension, is liable to embody opinions that derive from underlying ideologies" (Van Dijk 1995, p. 283).

In this section there are four sub-sections that cover different aspects of what has been theoretically discussed so far but applying the possible and actual outcomes in terms of the effects on Turkish foreign and security policy. The first subsection is to look at the brand of "Neo-Ottoman Foreign Policy" and the underlying reasons for its creation. The second subsection will examine the GWOT, with a focus on events in Iraq. Colour Revolutions are the subject of the third subsection, the fourth and final subsection examines the Arab Spring.

\subsection{Neo-Ottoman Foreign Policy: A Case of Obstructive Marketing?}

There has been an attempt to categorize Turkish foreign policy through the lens of ideologically based foreign policy brand visions (to create associations and expectations that regulate the resulting political relationships formed with foreign audiences and stakeholders). It has been often shaped in the binary reality of one brand or another - Kemalism or Neo-Ottomanism. Kemalism having its origins dating back to the founding of the Turkish Republic in 1923 and having three pillars: militant secularism; assimilative nationalism; and Westernisation. This represents a rejection of the Ottoman past. In the contemporary Western discourse, Kemalism is being challenged by Neo-Ottomanism, which "by contrast, sees positive elements in Turkey's Ottoman past and wants to draw on these elements to form a new synthesis in foreign and domestic policy" (Larrabee, 2010, p. 91). On the surface of things, it would be understood to be a rather counter-productive brand name for Turkish foreign policy given that not all the previous imperial subjects viewed Turkish rule favourably. It prompts the question if the use of the NeoOttoman Turkish foreign policy brand is an official name or a case of obstructive marketing? Thus, there is a necessity to delve into the very origins and use of the term Neo-Ottoman and its application to Turkish foreign policy. 
With the Justice and Development Party's re-orientation of foreign policy through attempts to cultivate closer ties with countries such as Iran, Syria, Sudan, the Gulf States and Russia created the operational environment where the concept of Neo-Ottoman foreign policy was more frequently used. ${ }^{4}$ The use of a Neo-Ottoman foreign policy vector is a deliberate strategy of obstructive foreign policy, which is using this brand to suggest a negative relational brand based upon associations with an imperial past that can potentially limit the prospects and ability of Turkish foreign and security policy to achieve its goals and objectives. It is not objectively accurate but is subjectively deliberate to limit the ability of Turkey to pursue an independent (of the US) foreign and security policy more effectively. Given that several the aforementioned countries are considered enemies or competitors to the United States (such as Iran, Russia and Syria), a negative reaction to the new independent foreign policy vector of Turkey would likely be a cause for worry and concern about the 'reliability' of Turkey as a so-called vassal state in the understanding of Brzezinski's strategic imperatives for maintaining US hegemony.

Given that there is a tendency for critics to use Davutoglu's foreign policy concept as NeoOttomanism, emphasizing the foreign policy activism of Turkey tends to occur in former Ottoman territories. The fact that there is an emphasis on creating economic interdependence seems to cast doubt on the validity of the label (Aras, 2009, p. 131). Neo-Ottomanism in effect becomes both a promise and a threat to countries in Turkey's neighbourhood that were once part of the Ottoman Empire. There is the implication of an expansionist Turkey in "re-engaging with territories once ruled by the Sultans, from the Balkans to Baghdad, in a drive to return Turkey to a place among the leadership of the Muslim world and the top ranks of international diplomacy." The use of the brand may be an effective tool in the international relations arsenal, especially by an actor that seeks to reduce the operational choices and effectiveness of another state on the international stage.

Neo-Ottomanism is a misleading brand name, which seems to be an exercise in obstructive marketing that is intended to reduce the credibility and attraction of Turkey among foreign countries, especially among the former parts of the Ottoman Empire. David Barchard (1985) demonstrated the historical use and reuse of the neo-Ottoman brand against Turkey when a foreign policy conflict emerged with a rival or competing country. The intention being to constrain Turkey by attacking the intangible assets (brand, reputation etc.) and soft power potential.

\subsection{Global War On Terrorism (GWOT)}

The GWOT nominally began as a reaction to the terrorist attacks on the United States mainland on 11 September 2001. Initially, President Bush attempted to brand the coming armed conflict

4 Cagaptay, S., The AKP's Foreign Policy: The Misnomer of 'Neo-Ottomanism', Op-Eds and Articles, The Washington Institute for Near East Policy, https://www.washingtoninstitute.org/policy-analysis/view/the-akps-foreign-policythe-misnomer-of-neo-ottomanism, 24 April 2009

5 Strauss, D., Turkey's Ottoman Mission, Financial Times, https://www.ft.com/content/af859474-d868-11de-b63a00144feabdc0 , 23 November 2009 (accessed 7 July 2019) 
as the Crusade Against Terrorism. However, owing to the rather self-fulfilling potential of such a brand to create a scenario from Huntingdon's Clash of Civilisations, which could benefit the terrorist forces meant GWOT was used as a more effective means of conveying 'legitimacy' across more stakeholders in an exercise of managing opinion and perception through reputation management.

Contemporary Turkish and US foreign policy aims, and goals did diverge before GWOT and in particular the US-led invasion of Iraq in March 2003. This occurred back in 1990-1991 with the First Gulf War. President Turgut Özal perceived the war as an opportunity to accrue benefits for Turkey (for example to advance Turkey's membership to the EU) by demonstrating its continued strategic importance and to solidify closer defence relations with the US. Instead, many costs were incurred, such as economic losses from pipeline fees and lost trade, furthermore the Kurdish issue became much more acute in Turkey and abroad through the establishment of a de fact Kurdish state in Northern Iraq that was under Western protection (Oguzlu, 2007, p. 92; Larrabee, 2010, p. 7-9). The establishment of the de facto Kurdish state was seen as an existential threat to the integrity of the Turkish state.

Consequently, when the US attacked and invaded Iraq in March 2003 that was narrated as being an integral part of the GWOT, remembering the results of helping the US in the First Gulf War and understanding the likely security risks that would emerge, Turkey refused to allow Turkish territory to be used against Iraq. Some US officials understood the vote in the Turkish parliament as demonstrating a lack of solidarity and an act of betrayal by a US ally (Larrabee, 2010, p. 12). Furthermore, the reluctance of the US to take decisive military action against the PKK or to allow Turkey to do so has further exacerbated tensions (Larrabee, 2010, p. 16). The deep-rooted security instability in Northern Iraq that was the result of the US regime change through the invasion and occupation of Iraq has created a significant security threat on Turkey's southern border and plays a role in the current and future foreign and security policy directions. The Kurdish question in Iraq has domestic as well as foreign hard security and political implications and consequences that resulted from the United States' unilateral military decision (Tank, 2005). However, Turkey's Iraq War policy has been influenced by several different factors, rather than being owed to a particular singular reason.

One researcher noted a host of different aspects that happened to coincide that directed Turkey's Iraq War policy. One of these was the Kurdish issue, which involved historical memory when the British supported Kurds for their own imperial ambitions against the Ottoman Empire. In 2003, several major external actors in Iraq revived some trauma of the disintegration of the Ottoman Empire that took place less than 100 years earlier. Simultaneously, political Islamists and Kurdish nationalists were challenging the secular and unitary identity of the country. This was also assisted by the collapse of the Soviet Union and the loss of the decades-old security identity (Altunisik, 2006, p. 193). The tensions were slightly reversed from 2007 when President Bush promised Turkey actionable intelligence against the PKK and the blessing to perform limited strikes against 
the PKK in Iraq (Larrabee, 2010, p. 19-20). Other points of contention have arisen, seemingly owing to the US strategic goals within the context of GWOT.

A criticism of the GWOT is the accusation that it is anti-Islamic in nature and given the leading role of the US, it negates the possibility of any useable soft power of its own. This does not exclude the possibility of using an ally as a proxy source of soft power. The US has been attempting to promote the idea of Turkey as a 'role model' for the Islamic world, but at the same time is supporting the Kurds in Iraq (and Syria). This has resulted in a backlash in the Kemalist debate. Through promoting the idea of "moderate" Islam, it flies in the face of adherence to secularism. The Kurdish issue is one that is seen as a critical hard security issue that threatens, there are some 30-40 million Kurds living in the Middle East, plus the United States ignoring Turkish interests and security are significant red flags in terms of potential threats (Hill \& Taspinar, 2006, p. 90). For example, the US military support for the People's Protection Units (YPG) in Syria, which is a branch of the Turkey-based Kurdistan Workers Party (PKK). Traditionally, Turkish foreign policy is very realist and unfamiliar with the democracy promotion rhetoric of the US, which is seen as a tool to extend their influence in Turkey's area of interest (Kiniklioglu \& Morkva, 2007, p. 548).

The GWOT has the hallmarks of a negative geopolitical regionalism that is led by the US, but various other countries have piggybacked on this security policy brand to achieve their own aims and goals and minimise possible risk. By risk, this is possible criticism or more concrete steps taken to manage the system of international relations for the primacy of the three geopolitical strategic imperatives to be upheld. Turkey assessed the situation and understood the risks of the military attack and occupation of Iraq as being fraught with danger for Turkish security and interests. Though, by not acting as a vassal state and allowing military actions to be taken from Turkish soil, a price was inflicted by the US and bilateral relations suffered. Although when weighing up the different costs involved, the correct course of action was taken, and this may have served Turkish foreign and security policy interests for the better.

\subsection{Colour Revolutions and Post-Soviet Space}

Historically, Russia and Turkey have been geopolitical rivals (Bayram \& Tufekci, 2018) and have fought various wars as the ultimate expression of a geopolitical regionalism. This was particularly notable in the Black Sea area and the Southern Caucasus. The Soviet Union's collapse in 1991 opened a great deal of potential and possibilities as well as challenges for Turkish trade and relations with several the former Soviet republics, especially in the South Caucasus and Central Asia. However, the opening of the Turkic world because of the collapse of the Soviet hegemony has not been matched by a significant expansion in Turkish influence. A Central Asian direction was seen as a possible way offset the foreign policy difficulties with the US and Europe. However, the EU views Turkey as a possible tool to help reduce Russian influence in post-Soviet space, with reference to the South Caucasus and Black Sea (Braun-Dorrell et al, 2018). Thus, there is a 
careful balancing act required by Turkey owing to the inter-connected geo-political and economic located in different yet linked geographical localities that have diverging and at times conflicting interests and goals.

As with the Arab Spring, the Colour Revolutions witnessed several neutral or pro-Russian leaders among the former Soviet Republics toppled by what the West referred to as 'popular' revolutions. There are similarities with Gerald Sussman's (2010) book on the use of branding and regime change in Central and Eastern Europe at the end of the Cold War, together with the US messianiclike approach to promoting 'democracy' that was applied with the use of military force in Iraq. In terms of a geopolitical regionalism, it saw the rolling back of Russian influence and the increase of the US in the region. The result thus far has been greater instability in the region, which has taken on the appearance of a geopolitical shatter belt in certain countries (such as Ukraine - see Jalilov \& Kelly, 2014). Thus, Russia viewed the developing geopolitical and security developments as a threat to state security.

It seems that Turkey did not consider the regional influence of Russia's political and economic ties, especially in Central Asia (Larrabee, 2010, p. 47-48). Turkey and Russia maintain a pragmatically based relationship not only in post-Soviet space, but also in the Middle East. The relationship between Turkey and Russia was initially based on trade but evolved to include the energy issue (Kiniklioglu \& Morkva, 2007, p. 548). Turkey's increasing alienation from the West (EU and US in particular) has facilitated the growing partnership and cooperation. This has caused some to state that the relations are based on an 'axis of the excluded' (Hill \& Taspinar, 2006). The relationship with Russia is not overly complex and is based upon concrete mutual problems and concerns that have evolved with time and geopolitical circumstance.

One of the components has been the rise of the Justice and Development Party (AKP), "and the subsequent emergence of its foreign policy ideology converged with the secular Kemalist elite's sense of frustration and produced a peculiar consensus to deepen the relationship with Russia" (Kiniklioglu \& Morkva, 2007, p. 548). However, on the surface, there is little peculiar about the growing relationship that is based on political and geopolitical pragmatism with mutual roots and perception of both Turkey and Russia that the US does not take their interests in to account and is expanding its influence in their respective neighbourhoods and areas of interest.

One of the regions where Turkey intended to play a greater role is in the Black Sea, which is considered as an inland sea firmly in the area of interest - geographically, historically, politically, economically, transportation wise, diplomatically and militarily. Initially Turkey sought to increase regional cooperation (a positive geopolitical regionalism of inclusion) among the littoral states. Turkey has the self-interest and motivation to attempt to initiate a positive regionalism in the Black Sea and to assume a leading role through the pro-active leadership. However, the other countries of the region do not seem to share the same level of enthusiasm and have not been persuaded by Turkey (Bayram \& Tufekci, 2018). Turkey has also articulated its foreign policy interests and goals in Eurasia, including in the Central Asian region. 
During the Cold War, Turkey did not express a foreign policy approach to the Eurasian region owing to the apparently unassailable Soviet hegemony. However, Turkish public opinion tended to have an emotional attachment towards the Turkic communities living in Central Asia, which is at times considered to be Turkey's fatherland. Post-1991 greater interest was shown in the region, with various markers of significance being attached. Firstly, the geographical location of the region, and secondly (and more significantly) the region is perceived to be the original land of the Turkic peoples (Fidan, 2010, p. 110). There is soft power potential in the ethnic and cultural ties (common history, language, religion, and lifestyle). "Cultural ties between Turkey and the Turkish communities of the region facilitated Turkey's relations with Central Asia" at the bilateral and multilateral levels (Fidan, 2010, p. 114). There are several other more pragmatic interests that drive potential cooperation as well, such as trade, energy, and security.

Fidan (2010, p. 121) noted the best avenue for Turkey's engagement in the region is to take an active pragmatic approach and not to try and impose self-definitions and identity formulations. Rather to learn from the past, to approach the region with solid policies and opening channels of dialogue with all significant local and foreign powers. A functionalist methodology is considered as being a reliable basis for creating a relational dynamic between Turkey and the region in a win-win spirit, rather than a zero-sum game of policy interaction. This is not based upon the rationality and logic of hard power application, but the emotional connections forged by kinship and culture that are mixed with the attraction of trade using a soft power approach.

\subsection{Arab Spring}

The Arab Spring took place across the Middle East and North Africa, which according to the script saw a 'grass roots democratic wave' topple several governments across the region, which was supported by the United States, UK, France, Saudi Arabia, and Qatar. The US was a powerful broker in this series of branded regime changes openly favouring and supporting the so-called opposition, where some events were included in the narrative such as Tunisia, Egypt, Libya, and Syria. Others were excluded, Yemen or Bahrain, for instance (Yakis, 2014; Karpovich, \& Manoilo, 2015). There are some similarities to the Colour Revolutions, not least of which is that it is a negative geopolitical regionalism of exclusion, where power and influence is being competed for by different regional and global actors (Carpenter, 2013). As such, the Arab Spring contained opportunities and threats for Turkish foreign and security policy interests.

Turkish foreign policy in the region prior to the Arab Spring was based on 'civilizational geopolitics' that was adhering to the principles of "mutual gain through economic interdependence and close political ties based on cultural affinity and Muslim Brotherhood" and not on the notion of 'democracy promotion' (Önis, 2012, p. 46). The AKP's soft power based foreign policy was encapsulated with the zero-problems with neighbours' strategy. However, dilemmas created by unavoidable trade-offs were created during the Arab Spring, joining a political agenda of regime change would cost Turkey's economic interests in the region (Önis, 2012, p. 48-49; Oguzlu, 2012). 
This would also signal a move away from pragmatism towards a more ideological and messianic foreign policy that would carry several risks, such as threats to Turkey's soft power, security threats, damage to economic and political stability.

Some analysts note that Turkey's engagement in the Arab Spring regime change policy, notably in Libya and Syria, has helped to bring the US and Turkey closer together (Tanir, 2011; Tocci et al, 2011). The message from the US and EU was positive concerning Turkey's 'cooperation' with the regime change agenda, but that this should not be expected to yield immediate positive results for the Turkish government from the West (Tocci et al, 2011). However, it places Turkey in a situation that was similar to the GWOT and the invasion and subsequent occupation of Iraq in 2003, together with the negative consequences for Turkeys foreign and security policy interests.

Turkey has also used the complexity of the Arab Spring in terms of the perplexing system of alliances and interests to forge some alternative ties. One such closer tie that has emerged is with Iran, where the two parties have found some middle ground. The middle ground is found in the area of hard security threats in which the two countries face threats from armed non-state groups. Thus, there is an indication of some semblance of a return to realpolitik owing to the specifics of the regional security environment. There are still differences, but also a lot of potential for cooperation in the MENA region (Aras \& Yorulmazlar, 2014). There is a similar security and geopolitical understanding between Turkey and Qatar as two ambitious geopolitical actors in the region, where the power vacuum created by the Arab Spring was too tempting. In addition, given the two countries complicated relations and suspicions of Saudi Arabia, it is an alliance of not only opportunity but also convenience (Pala \& Aras, 2015). These shifting and complicated sets of alliances create problems for the actualisation and operationalisation of concrete and appropriate policy that adequately serves self - interest.

Erdogan annoyed the US before the Syrian War within the Arab Spring by pursuing a rapprochement with Iran and Syria, viewed as part of the so-called Axis of Evil brand under George Bush's presidency. However, this changed in 2011, the Turkish government decided to join the cause of regime change in Syria. Ankara has provided aid and sanctuary to the 'rebel' cause in Syria to achieve this goal (Yakis, 2014). Even though Davutoglu saw potential for Turkey to 'control' events in Syria and gain influence, there are a significant number of risks too. One of these is an increase of Saudi influence on the Turkish border or Kurdish PKK forces gaining a further foothold in another part of Turkey's southern border (in addition to Northern Iraq), which are based upon a 'successful' outcome of the regime change plan. If the regime change is not successful, then risks may include a Syrian government that is resentful and deeply hostile towards Turkish interests or the increase of other regional geopolitical actors as Iran gaining influence (Tanir, 2011; Carpenter, 2013, p. 5-6). This is a risky venture by Turkey, which steps away from the pragmatic vector of foreign and security policy and moves towards a more ideologically/religiously based stance. As such, there is a risk of a deeply subjective perception that would misinform the decision-making process and create further 'unforeseen' security 
hazards and risks. Turkey's military intervention in Syria also marks a rather dramatic end to the zero problems with neighbours' policy.

Turkey has burned several bridges through its active support of the US-led regime change operations across the MENA region. The shift away from a win-win foreign policy approach to a subjective zero-sum game is highly likely to create significant problems where the regime change has failed, such as Syria. It is possible that Turkey shall be regarded with greater suspicion rather than neutrally or positively, by regional and international actors. The regime changes actions have also increased the instability in the region and significant problems for Turkey's security by exacerbating the Kurdish issue (Yakis, 2014). Kurds used the context of the Arab Spring brand to launch a brand of their own, a Kurdish Spring that was hoped to mobilise Kurds and included violent and non-violent actions (such as the civil disobedience campaign in Southeast Turkey for broader rights) (Noi, 2012, p. 23). Therefore, there is significant inherent risk involved in weakening Assad as the consequence could be the strengthening of Kurds along Turkey's southern border in Syria that is in addition to the existing problem in Iraq that was the result of US military intervention.

The Arab Spring has created the motivation and opportunity for a reconfiguration of the regional geopolitical order in the MENA region by local actors as Turkey (also Saudi Arabia, United Arab Emirates and Qatar) (Dihstelhoff \& Lohse, 2020). It has also created the context for a weakening of the US position and the rise of other foreign actors in the region, such as Russia that has been able to use its entry in the Syrian conflict to boost its standing and profile in the wider region (Simons, 2021). The shifting regional and global order has created a context where Turkey is varying between cooperation and competition with (re)emerging powers, such as Russia in Syria (but also Libya and the South Caucasus) (Önis \& Yilmaz, 2016; Aslam, 2019; Köstem, 2020). Köstem (2020, p. 16) characterises the relationship between Turkey and Russia in Syria as being an informal geopolitical alignment by two traditionally rival actors. The situation helps to support Russia's international brand identity as a great power and Turkey's brand role as a regional power and political power broker (Köstem, 2020, p. 17-18). These nuances are made possible by the transforming global geopolitical order.

This is also evidenced by the recent relations between Turkey and the European Union (EU) in the wake of the mass migration of refugees from the MENA region to Europe, where the role and position of Turkey has evolved. Formerly, the EU may have been considered to be in the stronger negotiating position as it expected Turkey to reform and change to its various political, social and economic requirements with the false promise of membership, therefore placing Turkey as a reactive and accommodating actor. However, with time and fatigue with the various escalating requirements and promises, the situation has evolved with the aftermath and consequences of US foreign and security policy (i.e., regime change) in the MENA region that precipitated a mass migration and refugee problem for the EU as well as Turkey. However, the mass migration issue in some EU countries has been evolving into an existential crisis for the legitimacy of mainstream liberal parties, giving Turkey an additional edge in the talks concerning the management of the 
refugee flows and Turkish involvement in the process (Muftuler-Bac, 2020; Cihangir-Tetik \& Muftuler-Bac, 2021).

\section{Conclusion}

The transforming global order towards a non-Western multipolar system presents an opportunity for medium sized regional actors to pursue independent (from great powers) foreign and security policy, through hard and soft power means to increase their influence, international standing and/or security (or other) interests. This can be potentially achieved through increased and more assertive diplomacy and public diplomacy programmes that target specific stakeholder audiences and interests. This does not mean to say, obstructive and coercive means will not be employed to prevent a deviation from the interests of great powers. During the Cold War confrontation between the United States led Western Bloc and the Soviet Union's Eastern Bloc, Turkey played a definite part in this bipolar world order. Turkey served as part of the frontier and served as a barrier to possible Soviet incursions, although as the events of the Cuban missile crisis showed, ${ }^{6}$ Turkey was an object of events rather than a subject in them. The collapse of the Soviet Union and the end of the Cold War in 1991 ushered in a new geopolitical era of a unipolar global order, and Turkey lost the role, together with a significant weight of possible risk. It also meant that the prominence of ideology in foreign and security policy could also be supplemented or supplanted with pragmatism. The situation created a chain of events that brought new risks and threats to Turkey, but also possibilities and opportunities that did not exist earlier. This enabled, at least to some extent, Turkey to shift from being an object to a subject of events with a repositioning of the foreign and security policy brand as a regional power.

In the contemporary practice of international relations and geopolitics in particular, actors need to be aware and consider the use of branding and other forms of reputation management as tools to increase the operational potential of the communicator and to decrease an opponent's policy choices and the effectiveness of their words and actions. This has been seen in the branding of the GWOT, Colour Revolutions and Arab Spring. It is also seen in the use of obstructive marketing through the labelling of Turkish foreign policy under the AKP government as 'NeoOttoman', which currently coincides with the country's attempts to pursue a more pro-active and independent foreign policy. These brands follow an emotional logic rather than a rational logic because audiences can be more readily primed and mobilised through the suggestions inherent in the associations and promises implied.

Turkey has been pursuing a foreign and defence policy that follows the logic of geopolitical regionalisms. Sometimes these approaches take on the spirit of a positive geopolitical regionalism, such as is usually the case of Turkish engagement in Central Asia and the Caucasus. This is a geopolitical regionalism of inclusion, where Turkey as a non-leading regional actor tries to create

6 The Cuban missile crisis was resolved with a compromise that included the US removing nuclear weapons that were based in Turkey, although there was no visible public sign that Turkey had much say in the issue. 
room for engagement and interaction through a win-win approach with domestic and external actors from this region. The emphasis with the local actors from the region is based on cultural and kinship ties as well as other more pragmatic considerations such as trade. GWOT and the Iraq War produced a negative, but defensively based geopolitical regionalism that resulted from the US's ignoring the serious and significant risks of its military adventurism in Iraq in terms of the security consequences for Turkey. This forced Turkey to take an independent geopolitical path that better served its regional interests and security, but somewhat alienated the US. The Arab Spring also yielded a negative geopolitical regionalism, which contradicted the previous pragmatic approach of zero problems with neighbours. By engaging in ideational foreign policy, most notably in Syria, Turkey has likely decreased its security and limited its foreign policy engagement potential.

Turkish soft power potential is created not only from the spirit of the foreign policy, and from influence that is created by a proactive and a physical presence in the Middle East and the territories of the former Soviet Union. This needs to be coupled with the development and realisation of political, economic, and cultural capabilities within the context of a relational foreign policy vector of mutually beneficial relationships between Turkey and those foreign audiences that are engaged with. The gradual drift away from a strong Western orientation in foreign and security policy is a natural outcome of the West not taking into account Turkey's foreign and security policy interests. A general lesson from the different cases in this paper is that a more pragmatic and less ideational approach is likely to yield better results for both foreign and security policy goals and is less likely to bring the chaos and upheaval of the Arab Spring engagement that has the potential for long-term negative consequences.

\section{References}

Altunisik, M. B. (2006), Turkey's Iraq Policy: The War and Beyond, Journal of Contemporary European Studies, 14(2), 183-196. https://doi.org/10.1080/147.828.00600892242

Aras, B. (2009), The Davutoglu Era in Turkish Foreign Policy, Insight Turkey, 11(3), 127-142. https://www. jstor.org/stable/26331107

Aras, B. \& Yorulmazlar, E. (2014), Turkey and Iran After the Arab Spring: Finding a Middle Ground, Middle East Policy, XXI(4), Winter, 112-120. https://doi.org/10.1111/mepo.12100

Aronczyk, M. (2013), Branding the Nation: The Global Business of National Identity, New York: Oxford University Press

Aslam, M. K. (2019), Turkish Foreign Policy in the Post-Arab Spring Period: A Case Study of Syria, Muslim Perspectives, IV(2), 1-25

Barchard, D. (1985), Turkey and the West, London: Routledge Chatham House Papers 27

Bayram, D. C. \& Tüfekçi, Ö. (2018), Turkey’s Black Sea Vision and its Dynamics, Karadeniz Arastirmalari, XV/57, 1-16. http://dx.doi.org/10.12787/KARAM1272

Bilgin, P. \& Bilgic, A. (2011), Turkey’s "New" Foreign Policy Towards Eurasia, Eurasian Geography and Economics, 52(2), 173-195. https://doi.org/10.2747/1539-7216.52.2.173

Braun-Dorrell, T., Kastetter, A., Manoli, P. \& de Pedro, N. (July 2018), EU-Turkey Relations: Security Drivers From the Eastern Neighbourhood, FUTURE Online Paper No. 23 (available from: http:// 
www.tepsa.eu/feuture-online-paper-no-23-eu-turkey-relations-security-drivers-from-the-easternneighbourhood/)

Brzezinski, Z. (1997), The Grand Chessboard: American Primacy and its Geostrategic Imperatives, New York: Basic Books

Cagaptay, S. (26 October 2009), Is Turkey Leaving the West?, Foreign Affairs, available at: https://www. foreignaffairs.com/articles/turkey/2009-10-26/turkey-leaving-west

Carpenter, T. G. (2013), Tangled Web: The Syrian Civil War and Its Implications, Mediterranean Quarterly, 24(1), Winter, 1-11. https://doi.org/10.1215/10474.552.2018988

Cihangir-Tetik, D. \& Muftuler-Bac, M. (2021), A Comparison of Development Assistance Policies: Turkey and the European Union in Sectoral and Humanitarian Aid, Journal of European Integration, 43(4), 439-457. https://doi.org/10.1080/07036.337.2020.1734587

Davutoglu, A. (2008), Turkey's Foreign Policy Vision: An Assessment of 2007, Insight Turkey, 10(1), 77-96

Dihstelhoff, J. \& Lohse, A. (2020), Political Islam as an Ordering Factor? The Reconfiguration of the Regional Order in the Middle East Since the Arab Spring, in Amour, P. O (Editor), The Regional Order in the Gulf Region and the Middle East, Cham: Springer, 29-59

Dinnie, K. (2008), Nation Branding: Concepts, Issues, Practice, London: Routledge

Eggling, K. A. (2020), Nation-Branding in Practice: The Politics of Promoting Sports, Cities and Universities in Kazakhstan and Qatar, London: Routledge

Erickson, E. J. (2004), Turkey as a Regional Hegemon - 2014: Strategic Implications for the United States, Turkish Studies, 5(3), 25-45. https://doi.org/10.1080/146.838.4042000270317

Fidan, H. (2010), Turkish Foreign Policy Towards Central Asia, Journal of Balkan and Near Eastern Studies, 12(1), 109-121. https://doi.org/10.1080/194.489.50903507560

Franklin, B., Hogan, M., Langley, Q., Mosdell, N. and Pill, E. (2009), Key Concepts in Public Relations, London: Sage

Hill, F. \& Taspinar, O. (2006), Turkey and Russia: Axis of the Excluded?, Survival, 48(1), 81-92. https://doi. org/10.1080/003.963.30600594256

Hyslop, M. (2014), Obstructive marketing: Restricting distribution of products and services in the age of asymmetric warfare, Farnham: Ashgate

Jalilov, M. \& Kelly, P. (30 October 2014), The Ukrainian Shatterbelt: A New Cold War?, I Report dell'IsAG

Jay, P. (1979), Regionalism as Geopolitics, Foreign Affairs 58(3), 485-514. https://doi.org/10.2307/20040490

Kaliber, A. (2013), The Post-Cold War Regionalisms of Turkish Foreign Policy, Journal of Regional Security, 8(1), 25-48. https://doi.org/10.11643/issn.2217-995X131SPK28

Karpovich, O. \& Manoilo, A. (2015), Colour Revolutions: Techniques in Breaking Down Modern Political Regimes, Bloomington (IN): Author House

Kiniklioglu, S. \& Morkva, V. (2007), An Anatomy of Turkish-Russian Relations, Southeast European and Black Sea Studies, 7(4), 533-553. https://doi.org/10.1080/146.838.50701726013

Köstem, S. (2020), Russian-Turkish Cooperation in Syria: Geopolitical Alignment with Limits, Cambridge Review of International Affairs, doi: 10.1080/09557.571.2020.1719040

Larrabee, S. F. (2010), Troubled Partnership: U.S.-Turkish Relations in an Era of Global Geopolitical Change, Arlington (VA): RAND Corporation

Lesser, I. O. (2006), Turkey, the United States and the Delusion of Geopolitics, Survival, 48(3), 83-96. https:// doi.org/10.1080/003.963.30600905460 
Matusitz, J. (2015), Symbolism in terrorism: Motivation, communication and behaviour, Lanham (MD): Rowman and Littlefield.

Muftuler-Bac, M. (June 2020), Turkey and the European Union Refugee Deal: Assessing Turkish Migration Policies and the External Protection of European Borders, Working Paper, Migration Governance and Asylum Crises (MAGYC) Project

Murinson, A. (2006), The Strategic Depth of Turkish Foreign Policy, Middle Eastern Studies, 42(6), 945-964. https://www.jstor.org/stable/4284512

Newman, B. I. (2016), The marketing revolution in politics: What recent U.S. presidential campaigns can teach us about effective marketing, Buffalo: University of Toronto Press.

Noi, A. U. (2012), The Arab Spring, Its Effects on the Kurds, and the Approaches of Turkey, Iran, Syria, and Iraq on the Kurdish Issue, Middle East Review of International Affairs, 16(2), 15-29

Oguzlu, T. (2004), Changing Dynamics of Turkey's US and EU Relations, Middle East Policy, XI(1), Spring, 98-105. https://doi.org/10.1111/j.1061-1924.2004.00144.x

Oguzlu, T. (2007), Soft Power in Turkish Foreign Policy, Australian Journal of International Affairs, 61(1), 81-97. https://doi.org/10.1080/103.577.10601142518

Oguzlu, T. (2008), Middle Easternisation of Turkey's Foreign Policy: Does Turkey Disassociate from the West?, Turkish Studies, 9(1), 3-20. https://doi.org/10.1080/146.838.40701813960

Oguzlu, T. (February 2012), The 'Arab Spring' and the Rise of the 2.0 Version of Turkey's 'Zero Problems With Neighbours' Policy, Centre for Strategic Research (SAM), SAM Papers No. 1

Önis, Z. (2012), Turkey and the Arab Spring: Between Ethics and Self-Interest, Insight Turkey, 14(3), 45-63

Önis, Z. \& Yilmaz, S. (2009), Between Europeanisation and Euro-Asianism: Foreign Policy Activism in Turkey During the AKP Era, Turkish Studies, 10(1), 7-24. https://doi.org/10.1080/146.838.40802648562

Önis, Z. \& Yilmaz, S. (2016), Turkey and Russia in a Shifting Global Order: Cooperation, Conflict and Asymmetric Interdependence in a Turbulent Region, Third World Quarterly, 37(1), 71-95. https:// doi.org/10.1080/01436.597.2015.1086638

Özdemir, E. \& Serin, Z. V. (2016), Trading State and Reflections of Foreign Policy: Evidence From Turkish Foreign Policy, Procedia Economics and Finance, 38, 468-475. Doi: 10.1016/S2212-5671(16)30218-0

Pala, Ö. \& Aras, B. (2015), Practical Geopolitical Reasoning in the Turkish and Qatari Foreign Policy on the Arab Spring, Journal of Balkan and Near Eastern Studies, 17(3), 286-302. https://doi.org/10.1080/1 9448.953.2015.1063274

Ruma, I. (2010), Turkish Foreign Policy Towards the Balkans: New Activism, Neo-Ottomanism Or/So What?, Turkish Policy Quarterly, 9(4), Winter, 133-140

Rumley, D. (2005), The Geopolitics of Asia-Pacific Regionalism in the $21^{\text {st }}$ Century, The Otemon Journal of Australian Studies 31, 5-27

Simons, G. (2011), Attempting to Re-Brand the Branded: Russia’s International Image in the $21^{\text {st }}$ Century, Russian Journal of Communication, Vol. 4, Nos. 3/4, Summer/Fall, 322-350. https://doi.org/10.1080/ 19409.419.2011.10756816

Simons, G. (2021), Hard and Soft Power Approaches to Armed Conflicts: The United States in Iraq and Russia in Syria, Russia in Global Affairs, 19(2), 86-110. https://eng.globalaffairs.ru/articles/hardand-soft-power-iraq-syria/

Sussman, G. (2010), Branding Democracy: US Regime Change in Post-Soviet Eastern Europe, New York: Peter Lang

Tanir, I. (2011), How the Arab Spring is Transforming Turkish-American Relations, Turkish Policy Quarterly, 10(3), Fall, 71-81 
Tank, P. (2005), Analysis: The Effects of the Iraq War on the Kurdish Issue in Turkey, Conflict, Security and Development, 5(1), 69-86. https://doi.org/10.1080/146.788.00500103309

Taspinar, Ö. (2011), The Rise of Turkish Gaullism: Getting Turkish-American Relations Right, Insight Turkey, 13(1), 11-17.

Tocci, N., Taspinar, Ö, Barkley, H. J., Lecha, E. S. \& Nafaa, H. (2011), Turkey and the Arab Spring: Implications for Turkish Foreign Policy From a Transatlantic Perspective, Mediterranean Paper Series, The German Marshall Fund of the United States

Tsantoulis, Y. (2009), Geopolitics, (Sub)Regionalism, Discourse and a Troubled 'Power Triangle' in the Black Sea, Southeast European and Black Sea Studies 9(3), 243-258. https://doi. org/10.1080/146.838.50902934168

Vilanova, P. (2013), The Fragmentation of Political Science and "Methodological Pluralism": Regionalism and Geopolitics, Geopolitica(s) 4(1), 11-33. Doi: 10.5209/rev_GEOP.2013.v4.n1.44060

Yakis, Y. (2014), Turkey After the Arab Spring: Policy Dilemmas, Middle East Policy, XXI(1), Spring, 98-106

Yanik, L. K. (2011), Constructing Turkish "Exceptionalism": Discourses of Liminality and Hybridity in Post-Cold War Turkish Foreign Policy, Political Geography, 30, 80-89. https://doi.org/10.1016/j. polgeo.2011.01.003 